\title{
Preliminary results on bird collision with overhead power lines in Hungary: a case study around Pusztaszer Landscape Protection Area
}

\author{
Csaba Pigniczki ${ }^{*}$, Zsolt BaKró-NAgY ${ }^{1}$, Gábor BAKACSI ${ }^{2}$, Csaba \\ BARKóCZI $^{3}$, Tamás NAGY ${ }^{4}$, József Puskás ${ }^{1} \&$ Róbert ENYEDI ${ }^{1}$
}

Received: April 21, 2019 - Revised: May 12, 2019 -Accepted: May 15, 2019

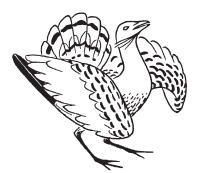

Pigniczki, Cs., Bakró-Nagy, Zs., Bakacsi, G., Barkóczi, Cs., Nagy, T., Puskás, J. \& Enyedi, R. 2019. Preliminary results on bird collision with overhead power lines in Hungary: a case study around Pusztaszer Landscape Protection Area. - Ornis Hungarica 27(1): 221-238. DOI: 10.2478/orhu-2019-0012

\begin{abstract}
The literature on bird collision with power lines in Hungary is rather limited. We collected published records and carried out research on birds that collided with overhead wires, and we made a list of species, and the number of individuals recorded, around Pusztaszer Landscape Protection Area. The quality of data did not allow us to do robust statistical tests, and a large amount of collected data was not used in this paper, because of uncertainty. Finally, we used the records of 519 individuals of 63 species that got injured or died during collision with overhead wires. We found evidence, that low-, middle- and high-voltage power lines were all responsible for the collision accidents of birds. Birds that use wetlands or both wetlands and farmlands are the most threatened to collide with overhead electric wires. Most victims of collision accidents belong to Gruiformes, Charadriiformes, Pelecaniformes and Anseriformes orders. Our preliminary results suggest that the bigger the rate of weight and wingspan (wing-loading proxy) is, the greater the risk of birds colliding with power lines, probably because of poor manoeuvrability. Birds that move regularly, on a daily basis between their nests/roost sites and foraging areas are at higher risk to collide with electric wires. Our preliminary results do not support the hypothesis that birds which sit on power lines collide more frequently than birds that do not use wires. It seems that foggy weather circumstances increase the probability of collision events particularly in case of Common Cranes. Some large birds were found with burnt feathers after collision with middle-voltage power lines. A sizeable part of collided birds were protected or strictly protected. Bird collision with overhead wires is a serious problem in Hungary. Collision can be stopped on most dangerous part of overhead wires by converting to underground cabling. It is possible to reduce the number of collision events in case of high-voltage power lines by increasing their visibility. We always recommend underground cabling in case of wetlands, if new segments of electric wires would be carried out.
\end{abstract}

Keywords: birds, collision risk, collision accident, electric overhead power line, habitat use, waterbird

Összefoglalás A madarak légvezetékkel történő ütközéséről Magyarországon csak minimális mennyiségủ adattal rendelkeztünk. A publikált adatokból és saját felméréseinkből összeállítottunk egy fajlistát, hogy mely fajokat érint a légvezetékkel történő ütközés, és hány egyed pusztult el vagy sérült meg a Pusztaszeri Tájvédelmi Körzetben és környékén. Az adatok minősége miatt megbízható statisztikai elemzéseket nem tudtunk végezni, és az eredetileg összegyüjtött adatok egy részét a bizonytalanságok miatt nem is használtuk fel ebben a tanulmányban. Végül 63 faj 519 egyedével dolgoztunk, melyek vezetékkel való ütközés következtében elpusztultak vagy megsérültek. A kis-, közép- és nagyfeszültségü vezetékeknél egyaránt tapasztaltunk madárpusztulást. A légvezetékkel történő ütközés leginkább olyan madarakat érintett, melyek vizes élőhelyeket, illetve vizes élőhelyeket és mezögazdasági területeket egyaránt használtak. Az ütközéses balesetekben leginkább a daru-, lile-, gödény- és lúdalkatú madarak érintettek. Előzetes adataink szerint minél nagyobb a testtömeg és a szárnyfesztávolság aránya (nagy a szárnyterhelést helyettesítő érték), annál inkább hajlamosak a madarak az ütközésre, valószínúleg a rossz manőverezöképességük miatt. Azok a madarak, melyek rendszeresen, naponta mozognak a fészkük/pihenöhelyük, 
és a táplálkozó-területük között, hajlamosabbak voltak arra, hogy légvezetéknek ütközzenek. Előzetes eredményeink nem támasztották alá azt, hogy a légvezetékeket rendszeresen használó madarakból több pusztul el ütközés miatt, mint azokból, amelyek nem használják ezeket. A darvaknál úgy tünik, hogy a köd fokozta az ütközéses esetek számát. Az ütközés során középfeszültségủ légvezetékeknél a nagyobb méretủ madarak egy része megégett. Az ütközött madarak nagy része védett vagy fokozottan védett volt. A légvezetékkel ütközés Magyarországon is komoly probléma. A legveszélyesebb vezetékszakaszok földkábelbe helyezése megszünteti az ütközést. A nagyfeszültségủ szakaszokon a láthatóság növelésével mérsékelhető a madarak légvezetékkel történő ütközéseinek száma. Javasoljuk, hogy vizes élőhelyeken és vizes élőhelyek között új elektromos vezeték csak földkábeles megoldással létesülhessen.

Kulcsszavak: madarak, ütközési kockázat, ütközéses baleset, elektromos légvezeték, élőhely-használat, vízimadár

${ }^{1}$ Kiskunság National Park Directorate, 6000 Kecskemét, Liszt Ferenc u. 19., Hungary
26726 Szeged, Blaha Lujza u. 24., Hungary
${ }^{3} 6763$ Szatymaz, IV. körzet, Tanya 100., Hungary
${ }^{4} 6767$ Ópusztaszer, Rontószél 170., Hungary
* corresponding author: csaba.spoonbill@gmail.com

\section{Introduction}

Humans create dozens of infrastructural facilities (e.g. power lines, roads, railways, wind farms, solar power plants), which have serious, and often fatal impacts on birds due to their direct or indirect effects (Trombulak \& Frissell 2000, Horváth \& Demeter 2010, Smith \& Dwyer 2016, Molnár \& Andrési 2019). A well-known direct effect of overhead power lines is that the wires and pylons regularly cause bird collision and electrocution of birds (Bevanger 1994, Horváth \& Demeter 2010). At the same time, electric cables may dramatically reduce the available habitat of some species, as a negative indirect effect (Lóránt \& Vadász 2014). Besides negative impacts, positive effects are also known: $80 \%$ of the Hungarian Saker Falcon (Falco cherrug) population breeds in artificial nest boxes that are insulated on high-voltage pylons (Bagyura et al. 2019).

National park directorates and civil associations regularly carry out surveys in Hungary to look for carcasses of birds that had been electrocuted (Horváth \& Demeter 2010, Demeter et al. 2018). Monitoring surveys indicated that protected and strictly protected species are often killed by electric shock in Hungary (Horváth \& Demeter 2010, Demeter et al. 2018). Electrocutions generally happen on middle-voltage power lines and sometimes they occur on low-voltage power lines as well, however, these were never documented on high-voltage power lines (Horváth \& Demeter 2010). Collision accidents could occur in all kinds of overhead power lines (low-, middle- and high-voltage), and also on the electric lines of railways (Horváth \& Demeter 2010, Vadász \& Lóránt 2014).

There could be several factors in the background of bird collisions:

(1) Morphological factors which influence the manoeuvrability of birds are probably one of the most important factors to understand why birds collide with power lines (D'Amico et al. 2019). Wing loading is the ratio of weight to wing area, whereas wing aspect ratio is the ratio of wingspan squared to wing area are the most important metrics to estimate manoeuvrability of an avian species (Bevanger 1994, Bernardino et al. 2018). Birds with high wing loading and low or average wing aspect ratio (for example in case of Anseriformes, 
Podicipediformes, Gruiformes, Charadriiformes) often collide with overhead wires (Quinn et al. 2011, Smith \& Dwyer 2016, Bernardino et al. 2018).

(2) Visual perception is another essential morphological factor that has impact on bird collision. Birds with binocular vision (e.g. raptors, owls) have better chance to locate obstacles and avoid collision, while birds with peripheral vision are less suitable for detection of wires in the air (D'Amico et al. 2019).

(3) Several behavioural factors also play key role during collision: birds that tend to fly in flocks are more often found as victims of collision than solitary species (Quinn et al. 2011, Bernardino et al. 2018). Some species (for example raptors and storks) usually move with soaring flight in higher altitudes than the height of power lines, and this behaviour feature prevent them from collision with power lines (Bernardino et al. 2018, D'Amico et al. 2019). Birds that migrate during night and also nocturnal birds are in higher risk to collide with power lines, because the wires are less visible during night (Bevanger 1994, Bernardino et al. 2018, D'Amico et al. 2018, 2019). Birds during their migration usually fly higher above wires and during their flight they are not expected to collide with power lines (Bernardino et al. 2018). Collisions generally happen when birds fly in low altitude from one site to another, and they cross power lines during their local, daily movements, often between foraging areas and nest (Bernardino et al. 2018). Display flights may also increase the risk of collision (Bevanger 1994, Bernardino et al. 2018). Juvenile birds collide more frequently with wires because young birds are less manoeuvrable and they are inexperienced (Bernardino et al. 2018).

(4) Visual circumstances are also important. We have already mentioned it as a higher risk for collision with wires during the night (Bevanger 1994, Bernardino et al. 2018) or during fog, because the detectability of wires in foggy weather or at night is poor (Molnár \& Andrési 2019).

(5) Weather circumstances have influence on flight altitude of birds: fog, rainfall and snowfall also force birds to fly at low altitudes, therefore increase the chance to collide with power lines (Bernardino et al. 2018).

(6) Site specific factors also play an important role in these collision incidents. Topographical leading lines are of great importance to migrating birds, and they may contribute to defining migratory flyways, like along rivers and topographical depressions, and electric wires above them would result in frequent collision events (Bevanger 1994, Quinn et al. 2011, Bernardino et al. 2018). Birds generally fly at lower altitudes above open areas, which means a higher risk for collision, while they tend to fly at higher altitude above forests, which may reduce collision risk (Bernardino et al. 2018). Electric wires above wetlands are assumed to be the most hazardous, because huge number of waterbirds can be found there during breeding season, or during their migration and wintering as well (Bevanger 1994, Quinn et al. 2011, Bernardino et al. 2018).

(7) The features of power lines are also important: there is a general agreement that the higher the structure is, the greater risk it becomes for birds (Bernardino et al. 2018).

(8) Anthropogenic disturbance (e.g. hunting) is also known as factor which increases the risk of collision (Bernardino et al. 2018).

While the mortality of birds caused by electrocution is more or less monitored in Hungary, the collision events of birds with overhead lines are less so. The goal of this paper is to draw attention to the serious problem of birds' collision with overhead power lines in Hungary. 


\section{Material and methods}

\section{Data collection}

Data used for this paper were collected by rangers and officers of Kiskunság National Park Directorate and also by amateur ornithologists. Data were collected from the Great Hungarian Plain, from Csongrád County, mainly from Pusztaszer Landscape Protection Area and the vicinity of this site. The collected data were geographically located between the area called "Homokhátság" and River Tisza (Figure 1). Data were collected without a strict protocol between 1982 and 2019, but the available dataset contains large gaps within this time period, with no surveys. This area has a rich avifauna, with huge number of wildfowls, herons, spoonbills, cranes, shorebirds and gulls (Máté \& Nagy 2015, Végvári 2015, Pigniczki 2016).

Data were collected from electric wires, which were located in fishpond systems (Lake Csaj, Fertő at Szeged) or between two fishpond systems (namely Lake Fehér and Fertő at Szeged), and some was located above meadows or agricultural fields. Generally, all of the electric wires were on open areas, and their distance from wetlands (fishponds, soda pans, marshes) was less than 1.5 kilometres. That is the reason why they have a direct impact on birds during their foraging trips, or when they move from a pond to another one, within a fishpond system. The low-voltage power lines were $8-10 \mathrm{~m}$ high, the middle-voltage were 10-14 m tall (A. Gerhardt pers. com.). The maximal height of pylons of high-voltage power lines were $50 \mathrm{~m}$ in the study area (Gy. Bíró pers. com.).

We collected information on the species; the number of individuals (if it was possible); type of power lines that caused collision accidents; the date (if it was possible) and the location of accidents. We noted if a bird had burnt feathers due to electrocution during the collision accident, and also noted, if a bird survived the collision with other injuries.

Unfortunately, no exact date, number and notes belonged to some of the data: however, we used some of those records with missing dates as well, especially, when relatively rare birds [for example Sanderling (Calidris alba) or Whimbrel (Numenius phaeopus)] were described. If relatively common birds [for example Grey Herons (Ardea cinerea), Great White Egrets (Ardea alba), Black-headed Gulls (Larus ridibundus), etc.] were mentioned with no exact background information, the record were excluded from the present study to avoid risk of double use of the same record. Therefore, the given number in case of most species means minimum number and can be even much larger in reality.

We used the data of published surveys of Hegedüs (1984) and Mészáros (1989) as well; both authors collected data about high-voltage power lines located between two fishpond system, namely between Fehér-tó and Fertő (the closest settlements are Szeged and Sándorfalva) during 1982-1983 and 1985-1986. We also used published data about accidents of a Kentish Plover (Charadrius alexandrinus) (Pigniczki 2006) and Common Cranes (Grus grus) (Bakacsi \& Puskás 2019). 
Cs. Pigniczki, Zs. Bakró-Nagy, G. Bakacsi, Cs. Barkóczi,

T. Nagy, J. Puskás \& R. Enyedi

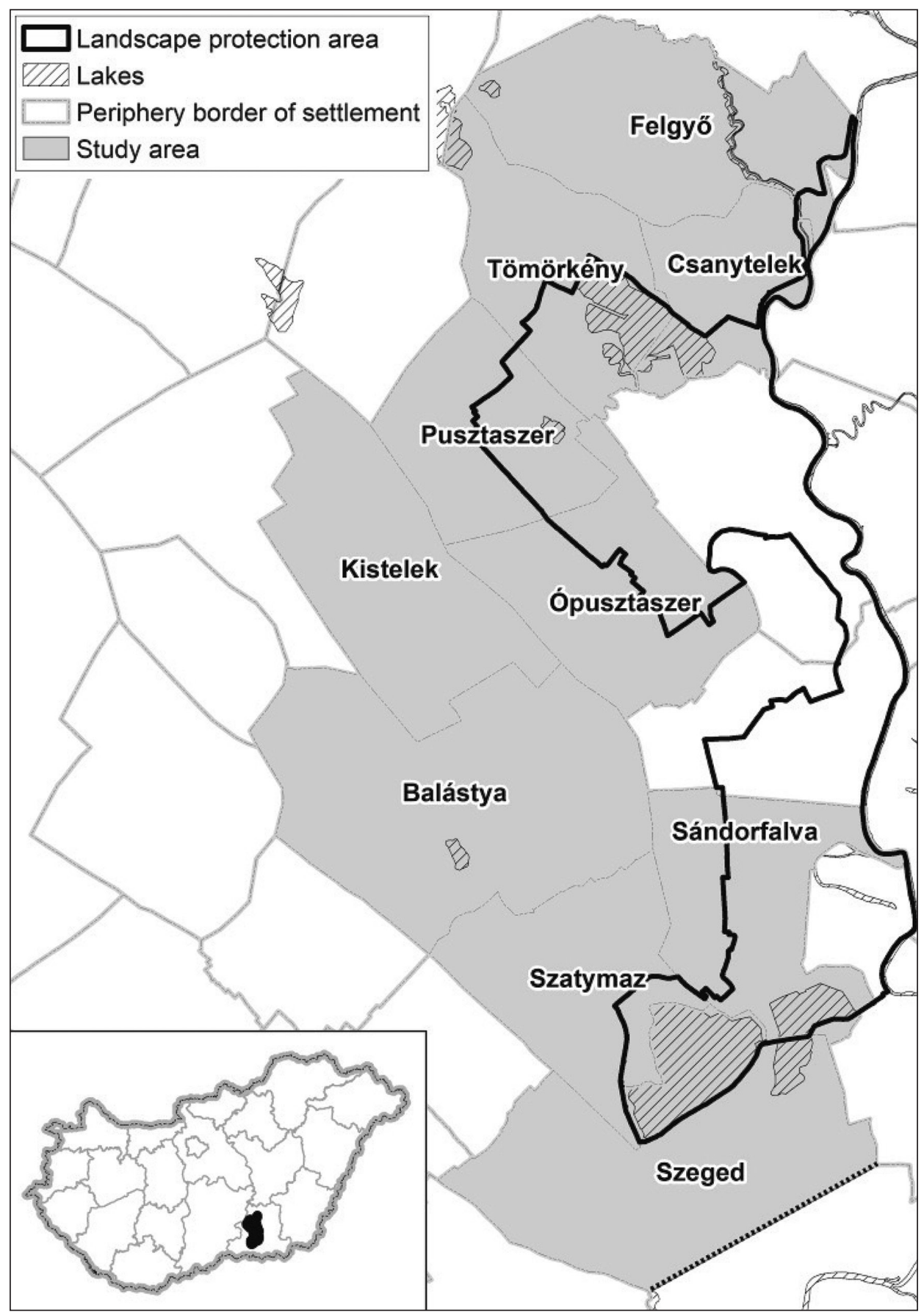

Figure 1. Map of study area

1. ábra A vizsgálati terület. Jelmagyarázat: landscape protection area: tájvédelmi körzet; lakes: tavak; periphery border of settlement: település külterület határa; study area: vizsgálati terület 


\section{Data analysis}

We created a list of species, with detailed information on mortality and injuries as a result of collision with power lines following the taxonomy available on the webpage of Handbook of Birds of the World (www.hbw.com). We collected wingspan, body length and body weight data (www.hbw.com and www.mme.hu/magyarorszagmadarai) for all the species that had collision accidents, to calculate wing-loading proxy, and to find measures for burning events during collision accidents. Wing area data were not available in case of most species to calculate wing-loading value (mass of the bird species divided by its wing area), thus, we used the ratio of weight of a given species (in gram) to its wingspan (in centimetre), and the result was called wing-loading proxy (D'Amico et al. 2019). If the value of wing-loading, or wing-loading proxy was high for a species, that meant poor manoeuvrability in flight and high risk of collision (Bernardino et al. 2018, D’Amico et al. 2019).

We determined the number of individuals and the number of species under the different type of power lines (high-, middle- and low-voltage), and compared them.

We compared the habitat use of species and the risk of collision during their flights. We used the following habitat types: wetlands (including rivers, lakes, fishponds, marshes, reedbeds, wet meadows), farmlands (including agricultural fields, dry grass-areas) and woodlands (including forests and bush-areas). We assigned one or two habitat types to each species. For example, if a species generally breeds or roosts in lakes or fishponds, but regularly forages on corn-fields, we assigned both wetland and farmland habitat types to that species [e.g. Common Crane, Mallard (Anas platyrhynchos), etc.)]. We compared the number of species and individuals with regard to the use of different habitat types.

We analysed which taxonomic orders and which species have high risk to collide with wires. We used the number of individuals collided to wires in both cases, and we used the number of species that belongs to a given taxonomic order to measure the impact of collision risk for different taxa.

We estimated the effect of power lines on birds that tend to have regular daily trips between foraging areas and their nests or roosting sites. We created two groups to compare: one of the groups contained species that had no regular, large-distance daily trips between areas, while the other group contained species that did have regular, long-distance daily trips between sites at least during a part of their annual cycle.

D'Amico et al. (2019) treated birds with higher collision risk if they bred on pylons, or hunt from wires/pylons. Other authors suggested that the use of power lines increases the chance of electrocutions significantly, but had no significant effect on collision risk (Bernardino et al. 2018, D'Amico et al. 2018). That is why we also estimated the collision risk, whether a species tend to use power lines to sit there, or not.

We created four interquartile range-groups based on the value of wing-loading proxy: the first group contains species between minimum and lower quartile values, the second group contains species between lower quartile and median value, species that fall between median and upper quartile are in the third group, and finally, the fourth group contains species, which fall between upper quartile and maximum values. We compared the number of individuals in case of the four groups. 
We described the chance of collision accidents, whether bird species tend to cover large distances regularly during its daily routine or not. These movements were generally foraging trips between breeding colonies and foraging areas [e.g. herons, spoonbills, ibises, gulls etc.], or between roosting areas and foraging sites [e.g. geese, Mallards, cranes, several species of shorebirds, like Lapwings (Vanellus vanellus), Eurasian Curlews (Numenius arquata), Whimbrels, gulls, Starling (Sturnus vulgaris), etc.]. Other bird species rarely move from one location to another, and they spend their time in a relatively small area (e.g. grebes, Aythya ducks, several species of shorebirds: Tringa species, Calidris species, small songbirds, etc.).

Four groups of conservation status were used in this study. We used the most recent conservation status in case of all species to determine, whether the species was a game species, protected species, strictly protected species, or not protected species (www.mme.hu/magyarorszagmadarai).

Rangers of Kiskunság National Park Directorate surveyed dead and injured cranes during foggy weather condition, but at the same time it was not monitored if any accident has happened in better weather conditions.

Occasionally, it was possible to note the cause of death or injury because of how visible they were: for example broken wings or broken neck. However, most of the events it was not possible to determine the cause of death or injury in the field. There were several occasions when birds that had been burnt during a collision were reported. These are only examples and probably not all broken-bone or burnt events were reported, therefore, the given number suggests a minimum number of this phenomenon in the current paper.

We used only descriptive statistical approaches because there was no standard survey in most cases, therefore, the result of statistical tests would be biased.

\section{Results}

519 specimens of 63 species were found dead or injured under overhead wires in the study area. This includes 3 individuals where species identification was not possible. In case of a further 7 specimens it was possible to reduce the possibilities to two or three species but their exact identity remained questionable.

\section{Type of electric cables and collisions of birds}

It was possible to clearly determine the type of electric wires, which caused the accidents in 517 cases: $79.7 \%$ of individuals were collected from under high-voltage power lines $(\mathrm{N}=$ 412), $19.9 \%$ of birds died or got injured because of collision with middle-voltage cables ( $\mathrm{N}$ $=103$ ) with only $0.4 \%$ of the carcasses were found under low-voltage power lines $(\mathrm{N}=2)$.

48 species collided with high-voltage power lines $(76.2 \%), 31$ species had accidents with middle-voltage power lines $(49.2 \%)$, while only two species were documented to have collisions with low-voltage power lines (3.2\%) out of 63 species. 


\section{General habitat use of birds and collisions with power lines}

Our results indicate that collision accidents with overhead lines have the largest impact on wetland species, together with those species which use both wetlands and farmlands (Table 1).

\section{Taxonomy of collided birds}

Most individuals found after collision accidents taxonomically belonged to Gruiformes (39.5\%), Charadriiformes (31.4\%), Pelecaniformes (10.5\%) and Anseriformes (10.3\%) order (Table 2).

Most species that collided with electric wires belonged to Charadriiformes (28.6\%), Passeriformes (17.5\%), Pelecaniformes (14.3\%), Anseriformes (12.7\%) and Gruiformes (9.5\%) (Table 2).

Table 1. Number and percentage of collision events of species and individuals regarded to habitat use

1. táblázat Az ütközéses esetek száma és százalékos aránya az élőhely-használati kategóriák alapján fajokra és egyedekre lebontva

\begin{tabular}{|l|c|c|c|c|}
\hline \multicolumn{1}{|c|}{ Habitat use } & $\begin{array}{c}\text { Number of } \\
\text { species }\end{array}$ & $\begin{array}{c}\text { Percentage of } \\
\text { species (\%) }\end{array}$ & $\begin{array}{c}\text { Number of } \\
\text { individuals }\end{array}$ & $\begin{array}{c}\text { Percentage of } \\
\text { individuals (\%) }\end{array}$ \\
\hline Wetland & 39 & 61.9 & 115 & 22.3 \\
\hline Wetland \& farmland & 11 & 15.9 & 375 & 72.7 \\
\hline Farmland & 8 & 12.7 & 13 & 2.5 \\
\hline Farmland \& forest & 2 & 3.2 & 10 & 1.9 \\
\hline Forest & 3 & 4.8 & 3 & 0.6 \\
\hline
\end{tabular}

Table 2. Number and percentage of collided species and individuals regarding to taxonomic orders 2. táblázat Az ütközéssel érintett madárfajok, illetve az ütközött egyedek száma és százalékos aránya madárrendenként

\begin{tabular}{|l|c|c|c|c|}
\hline \multicolumn{1}{|c|}{ Order } & $\begin{array}{c}\text { Number of } \\
\text { species }\end{array}$ & $\begin{array}{c}\text { Percentage of } \\
\text { species (\%) }\end{array}$ & $\begin{array}{c}\text { Number of } \\
\text { individuals }\end{array}$ & $\begin{array}{c}\text { Percentage of } \\
\text { individuals (\%) }\end{array}$ \\
\hline Galliformes & 1 & 1.6 & 2 & 0.4 \\
\hline Anseriformes & 8 & 12.7 & 53 & 10.3 \\
\hline Podicipediformes & 3 & 4.8 & 7 & 1.4 \\
\hline Columbiformes & 3 & 4.8 & 4 & 0.8 \\
\hline Gruiformes & 6 & 9.5 & 204 & 39.5 \\
\hline Pelecaniformes & 9 & 14.3 & 54 & 10.5 \\
\hline Suliformes & 2 & 3.2 & 3 & 0.6 \\
\hline Charadriiformes & 18 & 28.6 & 162 & 31.4 \\
\hline Strigiformes & 1 & 1.6 & 1 & 0.2 \\
\hline Accipitriformes & 1 & 1.6 & 1 & 0.2 \\
\hline Passeriformes & 11 & 17.5 & 25 & 4.8 \\
\hline
\end{tabular}


The most common victims of collision accidents were Common Cranes $(\mathrm{N}=190 ; 37.3 \%)$, Black-headed Gulls $(\mathrm{N}=114 ; 22.4 \%)$, Mallards $(\mathrm{N}=38 ; 7.5 \%)$, Lapwings $(\mathrm{N}=18 ; 3.5 \%)$, Grey Herons $(\mathrm{N}=15 ; 2.9 \%)$ and Great White Egrets $(\mathrm{N}=11 ; 2.2 \%)$ (Appendix 1). These calculations are based on exactly identified individuals $(\mathrm{N}=509 ; 100 \%)$.

\section{Wing-loading proxy and collided birds}

The calculated wing-loading proxy values of the victim-species ranged between 0.5545 [Sand Martin (Riparia riparia)] and 49.0909 [Mute Swan (Cygnus olor)], with variation regarding to species. The median of wing loading proxy in case of collided species is 4.4211, and the upper quartile value is 7.9491, while the lower quartile value is 2.2909 . One species of Galliformes, six species of Anseriformes, one species of Podicipediformes, two species of Gruiformes, three species of Pelecaniformes, two species of Suliformes and one species of Charadriiformes have higher wing-loading proxy value than upper quartile, with 276 individuals that had an accident. However, six species of Charadriiformes and ten species of Passeriformes have smaller wing-loading proxy value than lower quartile with 30 individuals that had an accident (Table 3, Appendix 1).

Table 3. Interquartile ranges of wing-loading proxies and the number of collided species and individuals belong to each range

3. táblázat A szárnyterhelést helyettesítő érték interkvartilis értékei és az ezekhez tartozó, ütközéssel érintett faj- és egyedszámok

\begin{tabular}{|l|c|c|c|}
\hline & $\begin{array}{c}\text { Interquartile range of } \\
\text { wing-loading proxies }\end{array}$ & $\begin{array}{c}\text { Number } \\
\text { of species }\end{array}$ & $\begin{array}{c}\text { Number of } \\
\text { individuals }\end{array}$ \\
\hline Group 1 & $0.5545-2.0270$ & 16 & 30 \\
\hline Group 2 & $2.5547-4.3059$ & 15 & 158 \\
\hline Group 3 & $4.4211-7.7692$ & 16 & 45 \\
\hline Group 4 & $8.1290-49.0909$ & 16 & 276 \\
\hline
\end{tabular}

\section{Regular movement between foraging areas and roosting or nesting sites and collision accidents}

Our results suggest that birds with regular, large distance movement have larger risk to die or get injured during a collision accident: among the victims 447 individuals $(86.6 \%)$ of 26 species tend to move between different areas during their daily routine, while 69 specimens $(13.4 \%)$ of 37 species belong to the group with no regular, large distance movements. Common Cranes have regular movements on a daily basis in the study area, and they had the most accidents on species level. Our data indicate that species belonging to Charadriiformes (145 individuals, 8 species), Pelecaniformes (50 specimens, 9 species) and Anseriformes (40 individuals, 2 species) orders also have higher risk of collision ( $A p$ pendix 1). 


\section{Collision risk and use of power lines by different species}

26 specimens $(5.0 \%)$ of eleven species, which regularly use power lines and pylons to sit on, died or got injured due to collision, while 490 individuals $(95.0 \%)$ of 52 species did not use wires and pylons (Appendix 1).

\section{Fog during collisions}

It was reported that 188 out of the190 individuals (98.9\%) of Common Cranes were found to be the victims of collision with power lines during, or shortly after foggy weather conditions between 2009-2017, while they were moving to or leaving their roosting sites at Lake Fehér, near Szeged and Sándorfalva, or Büdös-szék, near Pusztaszer.

\section{Injuries of birds during collisions}

It was documented several times (but not always) during surveys if the birds had visible and obvious injuries: broken wings were documented in case of Grey Heron (1 individual), Eurasian Spoonbill (Platalea leucorodia) (3 individuals), Common Cranes (2 individuals) while broken neck were noted in case of Eurasian Spoonbill (1 individual) and Black-headed Gull (1 individual).

Birds that collided with middle-voltage power lines might have suffered electrocution as well, if their body size were large (body length: $\geq 93.5 \mathrm{~cm}$; wingspan: $\geq 155 \mathrm{~cm}$ ). This phenomenon was documented in case of Mute Swan ( 1 individual), Great White Egret (1 individual), Grey Heron (2 individuals) and Common Cranes (4 individuals).

Birds may have survived their collision accidents but they could have broken their wings or suffered a concussion. As far as we know, two Spoonbills, 18 Common Cranes, one Lapwing, one Ruff (Calidris pugnax) and one Wood Sandpiper (Tringa glareola) were found alive. Eleven Common Cranes were set free from Szeged Zoo after they recovered from a collision accident with power lines. At the same time, two young Spoonbills had serious injuries such as broken wing bones and it was not possible to set them free.

\section{Conservation status of collided birds}

23 strictly protected species $(36.5 \%), 34$ protected species $(54.0 \%)$, one not protected species $(1.6 \%)$ and five game species $(7.9 \%)$ were found under electric cables due to collision accidents (Appendix 1).

60 specimens of strictly protected species (11.7\%), 406 individuals of protected species (78.8\%), two individuals of not protected species $(0.4 \%)$ and 47 specimens of game species $(9.1 \%)$ were reported from under electric cables as victims of collision accidents. 


\section{Discussion}

Our results shed new light on the problem of birds' collision with overhead power lines in Hungary. We collected data on 519 individuals of 63 species, which indicates that collision with power lines have serious impact on bird populations in Hungary.

We demonstrated that the vast majority of birds that collide with wires are protected or strictly protected. These accidents with overhead electric and railway cables are documented in case of some strictly protected species in Hungary, for example in case of Black Stork (Ciconia nigra) (B. Kalocsa pers. comm.), Great Bustard (Otis tarda) (Vadász \& Lóránt 2014), Eastern Imperial Eagle (Aquila heliaca) (Horváth et al. 2011), Short-toed Snakeeagle (Circaetus gallicus) (Molnár \& Andrési 2019) and Saker Falcon (Bagyura et al. 2018) as well. Several studies showed that the mortality during collision with power lines may had a significant impact on population level (Bernardino et al. 2018, D'Amico et al. 2018), which is important for conservation efforts to mitigate the effect of overhead wires on protected and strictly protected species.

We demonstrated that waterbirds suffered remarkable losses due to collision with electric cables in our study area, including species with unfavourable conservation status and declining trends worldwide [e.g. Black-tailed Godwits (Limosa limosa), Eurasian Curlews (Numenius arquata)] (www.iucnredlist.org), and species with dramatic decline in Hungary (e.g. Kentish Plover) (Pigniczki 2006). Waterbirds are one of the most affected species-group worldwide especially when these collision accidents are considered. These birds are regularly found at wetlands in large numbers, and wires overhanging these wetlands have a serious impact on their populations (Bevanger 1994, Quinn et al. 2011, Smith \& Dwyer 2016).

There are several reasons why birds are more susceptible to these accidents, for example, bad visual conditions, morphological and behavioural characteristics of species (Quinn et al. 2011, Smith \& Dwyer 2016, D’Amico et al. 2019, Molnár \& Andrési 2019). Our preliminary results support that wing-loading proxy has large effect on the probability of collision accidents, and the most affected species are birds with high wing-loading proxy-values: species with heavy weight and relatively small wings (e.g. swans, geese, ducks) or birds with broad wings (e.g. herons, spoonbills, cranes); both biometrical characteristics result poor manoeuvrability, and higher risk for collision accidents (Quinn et al. 2011, Bernardino et al. 2018, D'Amico et al. 2019). Based on our preliminary results, it seems that species, which cover large distances during their everyday-movements between their foraging areas and breeding/roosting sites have a larger chance to collide with overhead lines, especially, if the sites are close to each other and birds fly between those areas in low altitude (Bernardino et al. 2018). Our preliminary results do not support the hypothesis that birds using pylons as nesting sites or sitting sites during their hunt may have a higher risk of collision. Generally, authors treat these kinds of behavioural characteristics as high risk factor for electrocution, rather than risk of collision (Bernardino et al. 2018, D'Amico et al. 2018).

We found evidence, that low-, middle- and high-voltage power lines are all responsible for the collision accidents of birds. We detected the most collision accidents of birds around 
high-voltage power lines. Most surveys were conducted around high-voltage power lines, however, it is important to note that those involved in the study did not carry out the same amount of searches around low-voltage power lines.

The number of birds that had a collision accident in our study area could be much larger than we have published in this paper. However, data collection was not done regularly and there were no exact notes on carcasses in many times, that is why we may have missed a huge amount of information on the number of individuals and species as well. Results are also influenced by detectability: a large number of individuals would be never detected, if they fall into water or reedbed, and small species are also difficult to find (Borner et al. 2017). Furthermore, many injured or dead birds could be collected by predators, in which case carcasses can never be found and never reported (Molnár \& Andrési 2019).

It would be possible for the risk of collision to be stopped with underground cabling used instead of overhead wires (Bevanger 1994, Bernardino et al. 2018); this method should be applied especially in wetland habitats, because of the high number of victims and high number of protected and strictly protected species. We always recommend underground cabling in case of wetlands, if authorities give permission to carry out new line segments of electric wires. It is possible to mitigate the effect of overhead wires on birds using visual markers (Bevanger 1994, Bernardino et al. 2018), especially in case of high-voltage lines.

It is crucial to have a conflict map about birds' possible collision risk (Horváth \& Demeter 2010, D'Amico et al. 2019). To create this conflict map, it is essential to collect data and information about distribution, morphological and behavioural characteristics of bird species, and about the conservation status of these species as well. This would enable scientists to create a priority rank of species (Horváth \& Demeter 2010, D'Amico et al. 2019). We suggest adopting the formula of D'Amico et al. (2019) to create the priority rank of the species, but with some modifications: we think that the use of power lines by birds do not mean a larger risk for collision accidents (Bernardino et al. 2018, D'Amico et al. 2018), therefore, we recommend to exclude this from the ranking formula. Species that cover large distances regularly during their daily movements are at high risk (Bernardino et al. 2018), which makes it crucial that this behavioural characteristic is used in the ranking formula.

Our results show that a wide range of species could be found under electric wires. It is essential to understand which habitat characteristics and which type of wires have a large impact on collision accidents. It is also important to have good quality data on when collision accidents happen and to have information on the exact number of different species affected by collisions. The only way to have this data is to run a well-designed monitoring program. Tracking flight altitude of birds with GPS-technologies makes also possible to understand better the collision risk of birds with overhead wires. Research into this option is currently running including Spoonbills in Kiskunság National Park (Cs. Pigniczki unpublished data).

We believe that this paper will motivate professional and amateur ornithologists to scout for dangerous lines in Hungary and help the staff of national park directorates and electric companies to solve this problem, or to provide alternative solutions to mitigate the number of collision accidents of birds with overhead power lines. 


\section{T. Nagy, J. Puskás \& R. Enyedi}

\section{Acknowledgement}

We are grateful to László Engi, Csaba Mészáros, Zsolt Pataki, András Rácz and László Tajti for providing us their data and helping us with information to write this paper. We thank Zsolt Karcza to provide us data from the dataset of Hungarian Bird Ringing Centre on the repatriated Common Cranes. We are grateful for Tibor Csörgő, Réka Kapócs and János Oláh for their help to find data in literature and for Fruzsina Köhalmi for her contribution creating map. We thank Attila Gerhardt and Ildikó Plavecz from the electric company 'NKM Áramszolgáltató Zrt' and György Bíró from MAVIR Hungarian Independent Transmission Operator Company Ltd. for providing information on power lines that belong to their company. We wish to thank Zsuzsa Lugosi and Andrew Bloomfield for improving the English text. The activity of Kiskunság National Park Directorate to survey electrocution and collision with electric wires during 2018 and 2019 was supported by Ministry of Agriculture (grant number TMF/344/9/2018).

\section{References}

Bagyura, J., Fidlóczky, J., Szitta, T., Haraszthy, L. \& Prommer, M. 2018. A Kerecsensólyom-védelmi Munkacsoport 2016. évi beszámolója [Annual report of the Saker Falcon Conservation Working Group (2016)]. - Heliaca 14: 61-65. (in Hungarian with English Summary)

Bagyura, J., Prommer, M., Cserkész, T., Váczi, M. \& Tóth, P. 2019. A kerecsensólyom (Falco cherrug) állományváltozásának okai az elmúlt 120 évben, különös tekintettel a 2007-2018 közötti időszakra [Reasons behind the population changes of the Saker Falcon (Falco cherrug) in Hungary in the past 120 years, in particular with regard to the period between 2007 and 2018]. - Heliaca 15: 49-70. (in Hungarian with English Summary)

Bakacsi, G. \& Puskás, J. 2019. Darvak ütközése elektromos légvezetékkel [Collision of Common Cranes with electric wires]. - In: Molnár, Gy. \& Andrési, P. (eds.) A civilizáció káros hatásai az élővilágra Magyarországon [Negative impacts of civilisation on wildlife in Hungary]. - Typotex Kiadó, Szeged (in Hungarian)

Bernardino, J., Bevanger, K., Barrientos, R., Dwyer, J. F., Marques, A. T., Martins, R. C., Shaw, J. M., Silva, J. P. \& Moreira, F. 2018. Bird collisions with power lines: State of the art and priority areas for research. - Biological Conservation 222: 1-13. DOI: 10.1016/j.biocon.2018.02.029

Bevanger, K. 1994. Bird interactions with utility structures: collision and electrocution, causes and mitigating measures. - Ibis 136: 412-425. DOI: 10.1111/j.1474-919X.1994.tb01116.x

Borner, L., Duriez, O., Besnard, A., Robert, A., Carrere, V. \& Jiguet, F. 2017. Bird collision with power lines: estimating carcass persistence and detection associated with ground search surveys. - Ecosphere 8(11): e01966. DOI: $10.1002 /$ ecs 2.1966

D’Amico, M., Catry, I., Martins, R. C., Ascensão, F., Barrientos, R. \& Moreira, F. 2018. Bird on the wire: Landscape planning considering costs and benefits for bird populations coexisting with power lines. - Ambio 47: 650-656. DOI: 10.1007/s13280-018-1025-z

D’Amico, M., Martins, R. C., Álvarez-Martínez, J. M., Porto, M., Barrientos, R. \& Moreira, F. 2019. Bird collisions with power lines: Prioritizing species and areas by estimating potential population-level impacts. - Diversity and Distributions DOI: 10.1111/ddi.12903

Demeter, I., Horváth, M., Nagy, K., Görögh, Z., Tóth, P., Bagyura, J., Solt, Sz., Kovács, A., Dwyer, J. \& Harness, R. 2018. Documenting and reducing avian electrocutions in Hungary: A conservation contribution from citizen scientists. - The Wilson Journal of Ornithology 130: 600-614. DOI: 10.1676/17-031.1.

Hegedüs, Z. 1984. Madárpusztulások magasfeszültségü vezetékek alatt [Dead birds under high-voltage power lines]. - Madártani Tájékoztató 8(1): 16-17. (in Hungarian)

Horváth, M. \& Demeter, I. (eds.) 2010. Madarak és légvezetékek [Birds and power lines]. - MME, Budapest (in Hungarian) 
Horváth, M., Demeter, I., Fatér, I., Firmánszky, G., Kleszó, A., Kovács, A., Szitta, T., Tóth, I., Zalai, T. \& Bagyura, J. 2011. Population dynamics of the Eastern Imperial Eagle (Aquila heliaca) in Hungary between 2001 and 2009. - Acta Zoologica Bulgarica 2011 (Suppl. 3): 61-70.

Lóránt, M. \& Vadász, Cs. 2014. The effect of above-ground medium voltage power lines on displaying site selection of Great Bustard (Otis tarda) in Central Hungary. - Ornis Hungarica 22(1): 42-49. DOI: 10.2478/ orhu-2014-0017

Máté, A. \& Nagy, T. 2015. Az Alsó Tisza mente - az állatvilág [The area of lower Tisza - the fauna]. - In: Iványosi Szabó, A. (ed.) A Kiskunsági Nemzeti Park Igazgatóság negyven éve [Forty years of Kiskunság National Park Directorate]. - Kiskunsági Nemzeti Park Igazgatóság, Kecskemét, pp. 286-294.

Mészáros, Cs. 1989. Elektromos vezetékek okozta madárpusztulások a Gyevi-fertőnél [Collision of birds with power lines at Gyevi-fertö]. - Madártani Tájékoztató 13(1): 21. (in Hungarian)

Molnár, Gy. \& Andrési, P. (eds.) 2019. A civilizáció káros hatásai az élővilágra Magyarországon [Negative impacts of civilisation on wildlife in Hungary]. - Typotex Kiadó, Szeged (in Hungarian)

Pigniczki, Cs. 2006. Fajmegőrzési tervek: Széki lile (Charadrius alexandrinus) [Single species action plans: Kentish Plover]. - Környezetvédelmi és Vízügyi Minisztérium, Természetvédelmi Hivatal, Budapest (in Hungarian)

Pigniczki, Cs. 2016. Observation of an unusually large flock of roosting Spoonbills (Platalea leucorodia) on Büdös-szék of Kiskunság. - Aquila 122-123: 131-132.

Quinn, M. S., Heck, N., Alexander, S. M. \& Chernoff, G. 2011. Identification of bird collision hotspots along transmission power lines in Alberta: An expert-based geographic information system (GIS) approach. - Journal of Environmental Informatics 18: 12-21. DOI: 10.3808/jei.201100194

Smith, J. A. \& Dwyer, J. F. 2016. Avian interactions with renewable energy infrastructure: An update. - The Condor 118: 411-423. DOI: 10.1650/CONDOR-15-61.1

Trombulak, S. C. \& Frissell, C. A. 2000. Review of ecological effects of roads on terrestrial and aquatic communities. - Conservation Biology 14(1): 18-30. DOI: 10.1046/j.1523-1739.2000.99084.x

Vadász, Cs. \& Lóránt, M. 2014. Key mortality causes of the Great Bustard (Otis tarda) in Central Hungary: an analysis of known fatalities. - Ornis Hungarica 22(1): 32-41. DOI: 10.2478/orhu-2014-0016

Végvári, Zs. 2015. Autumn crane migration and climate change in the Carpathian Basin. - Ornis Hungarica 23(2): 31-38. DOI: 10.1515/orhu-2015-0012

www.hbw.com Accessed on 30 $30^{\text {th }}$ March 2019

www.iucnredlist.org Accessed on $3^{\text {rd }}$ April 2019

www.mme.hu/magyarorszagmadarai Accessed on 30 $0^{\text {th }}$ March 2019 


\section{Appendix}

Appendix 1. List of collided species with overhead power lines; their conservation status in Hungary; the number of individuals found under different types of electric wires; the habitat preferency of species; wingspan (WS) measured in centimetres; weight (W) in grams; wing-loading proxy (WLP); information on regular, large distance movements of species (T) (0 - no regular large distance movement, 1 - regular, large distance movement); information on use of electric cables (U) ( 0 - no use, $1-$ use)

1. függelék Légvezetéknek ütközött fajok listája, természetvédelmi helyzete Magyarországon (not protected: nem védett; game species: vadászható faj; protected: védett; strictly protected: fokozottan védett), az egyes vezetéktípusok alatt megtalált egyedek száma, a fajok jellemző élőhelye, szárnyfesztávolsága (WS) centiméterben, tömege (W) grammban, szárnyterhelést helyettesítő értéke (WLP), a fajok rendszeres, nagy távolságú mozgására vonatkozó információ (T) (0 - nincs ilyen mozgás, 1 - van ilyen mozgás), vezetékhasználatra vonatkozó információ (U) (0 - nem használja a vezetéket, 1 - használja a vezetéket)

\begin{tabular}{|c|c|c|c|c|c|c|c|c|c|c|c|}
\hline \multirow[b]{2}{*}{ Order/Species } & \multirow{2}{*}{$\begin{array}{l}\text { Conserva- } \\
\text { tion } \\
\text { status in } \\
\text { Hungary }\end{array}$} & \multicolumn{4}{|c|}{$\begin{array}{l}\text { Type of power } \\
\text { line }\end{array}$} & \multirow[b]{2}{*}{ Habitat } & \multirow[b]{2}{*}{ WS } & \multirow[b]{2}{*}{ W } & \multirow[b]{2}{*}{ WLP } & \multirow[b]{2}{*}{$\mathbf{T}$} & \multirow[b]{2}{*}{$\mathbf{U}$} \\
\hline & & 离 & 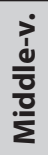 & جذا ذِ & 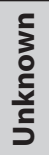 & & & & & & \\
\hline $\begin{array}{l}\text { Unknown/ } \\
\text { Ismeretlen }\end{array}$ & - & 3 & 0 & 0 & 0 & - & - & - & - & - & - \\
\hline \multicolumn{12}{|l|}{ Galliformes } \\
\hline $\begin{array}{l}\text { Phasianus } \\
\text { colhicus }\end{array}$ & $\begin{array}{c}\text { game } \\
\text { species }\end{array}$ & 2 & 0 & 0 & 0 & farmland & 80 & 1189.5 & 14.8688 & 0 & 0 \\
\hline \multicolumn{12}{|l|}{ Anseriformes } \\
\hline Cygnus olor & protected & 0 & 3 & 0 & 0 & wetland & 220 & 10800 & 49.0909 & 0 & 0 \\
\hline Anser albifrons & $\begin{array}{c}\text { game } \\
\text { species }\end{array}$ & 0 & 1 & 0 & 0 & $\begin{array}{l}\text { wetland- } \\
\text { farmland }\end{array}$ & 147.5 & 2587.5 & 17.5424 & 1 & 0 \\
\hline Anser sp. & $\begin{array}{c}\text { game } \\
\text { species }\end{array}$ & 1 & 0 & 0 & 0 & $\begin{array}{l}\text { wetland- } \\
\text { farmland }\end{array}$ & - & - & - & 1 & 0 \\
\hline Aythya ferina & protected & 2 & 1 & 0 & 0 & wetland & 77 & 845.5 & 10.9805 & 0 & 0 \\
\hline Aythya nyroca & $\begin{array}{c}\text { strictly } \\
\text { protected }\end{array}$ & 2 & 0 & 0 & 0 & wetland & 65 & 597.75 & 9.1962 & 0 & 0 \\
\hline $\begin{array}{l}\text { Spatula } \\
\text { querquedula }\end{array}$ & $\begin{array}{c}\text { strictly } \\
\text { protected }\end{array}$ & 2 & 0 & 0 & 0 & wetland & 63.5 & 401.25 & 6.3189 & 0 & 0 \\
\hline Spatula clypeata & protected & 1 & 0 & 0 & 0 & wetland & 77.5 & 630 & 8.1290 & 0 & 0 \\
\hline $\begin{array}{l}\text { Anas } \\
\text { platyrhynchos }\end{array}$ & $\begin{array}{l}\text { game } \\
\text { species }\end{array}$ & 33 & 5 & 0 & 0 & $\begin{array}{l}\text { wetland- } \\
\text { farmland }\end{array}$ & 87.5 & 1181.25 & 13.5000 & 1 & 0 \\
\hline Anas crecca & protected & 2 & 0 & 0 & 0 & wetland & 61 & 325 & 5.3279 & 0 & 0 \\
\hline \multicolumn{12}{|l|}{ Podicipediformes } \\
\hline $\begin{array}{l}\text { Tachybaptus } \\
\text { ruficollis }\end{array}$ & protected & 1 & 1 & 0 & 0 & wetland & 42.5 & 183 & 4.3059 & 0 & 0 \\
\hline Podiceps cristatus & protected & 2 & 2 & 0 & 0 & wetland & 87.5 & 1043 & 11.9200 & 0 & 0 \\
\hline $\begin{array}{l}\text { Podiceps } \\
\text { nigricollis }\end{array}$ & $\begin{array}{l}\text { strictly } \\
\text { protected }\end{array}$ & 0 & 1 & 0 & 0 & wetland & 50.5 & 357.5 & 7.0792 & 0 & 0 \\
\hline
\end{tabular}




\begin{tabular}{|c|c|c|c|c|c|c|c|c|c|c|c|}
\hline \multirow[b]{2}{*}{ Order/Species } & \multirow{2}{*}{$\begin{array}{c}\text { Conserva- } \\
\text { tion } \\
\text { status in } \\
\text { Hungary }\end{array}$} & \multicolumn{4}{|c|}{$\begin{array}{l}\text { Type of power } \\
\text { line }\end{array}$} & \multirow[b]{2}{*}{ Habitat } & \multirow[b]{2}{*}{ WS } & \multirow[b]{2}{*}{ w } & \multirow[b]{2}{*}{ WLP } & \multirow[b]{2}{*}{$\mathbf{T}$} & \\
\hline & & 交 & $\frac{\dot{d}}{\frac{\dot{d}}{\sigma}}$ & نإ & $\begin{array}{l}\frac{5}{3} \\
0 \\
\frac{j}{c} \\
\frac{\mathbf{c}}{5}\end{array}$ & & & & & & $\mathbf{U}$ \\
\hline \multicolumn{12}{|l|}{ Columbiformes } \\
\hline $\begin{array}{l}\text { Columba livia f. } \\
\text { domestica }\end{array}$ & $\begin{array}{c}\text { not } \\
\text { protected }\end{array}$ & 0 & 2 & 0 & 0 & farmland & 69.5 & 300 & 4.3165 & 0 & 1 \\
\hline $\begin{array}{l}\text { Streptopelia } \\
\text { turtur }\end{array}$ & protected & 0 & 1 & 0 & 0 & $\begin{array}{l}\text { woodland- } \\
\text { farmland }\end{array}$ & 50 & 134.5 & 2.6900 & 0 & 1 \\
\hline $\begin{array}{l}\text { Streptopelia } \\
\text { decaocto }\end{array}$ & $\begin{array}{c}\text { game } \\
\text { species }\end{array}$ & 1 & 0 & 0 & 0 & farmland & 51 & 179.5 & 3.5196 & 0 & 1 \\
\hline \multicolumn{12}{|l|}{ Gruiformes } \\
\hline Rallus aquaticus & protected & 1 & 1 & 1 & 0 & wetland & 41.5 & 122.5 & 2.9518 & 0 & 0 \\
\hline Crex crex & $\begin{array}{c}\text { strictly } \\
\text { protected }\end{array}$ & 1 & 0 & 0 & 0 & wetland & 47.5 & 158.75 & 3.3421 & 0 & 0 \\
\hline Porzana porzana & protected & 2 & 0 & 0 & 0 & wetland & 39.5 & 102 & 2.5823 & 0 & 0 \\
\hline $\begin{array}{l}\text { Gallinula } \\
\text { chloropus }\end{array}$ & protected & 3 & 1 & 0 & 0 & wetland & 52.5 & 319.25 & 6.0810 & 0 & 0 \\
\hline Fulica atra & $\begin{array}{c}\text { game } \\
\text { species }\end{array}$ & 4 & 0 & 0 & 0 & wetland & 75 & 892.5 & 11.9000 & 0 & 0 \\
\hline Grus grus & protected & 159 & 31 & 0 & 0 & $\begin{array}{l}\text { wetland- } \\
\text { farmland }\end{array}$ & 232.5 & 5400 & 23.2258 & 1 & 0 \\
\hline \multicolumn{12}{|l|}{ Pelecaniformes } \\
\hline $\begin{array}{l}\text { Platalea } \\
\text { leucorodia }\end{array}$ & $\begin{array}{c}\text { strictly } \\
\text { protected }\end{array}$ & 3 & 4 & 0 & 0 & wetland & 125 & 1545 & 12.3600 & 1 & 0 \\
\hline $\begin{array}{l}\text { Plegadis } \\
\text { falcinellus }\end{array}$ & $\begin{array}{c}\text { strictly } \\
\text { protected }\end{array}$ & 0 & 1 & 0 & 0 & wetland & 87.5 & 595 & 6.8000 & 1 & 0 \\
\hline Botaurus stellaris & $\begin{array}{c}\text { strictly } \\
\text { protected }\end{array}$ & 0 & 1 & 0 & 0 & wetland & 130 & 1152.5 & 8.8654 & 1 & 0 \\
\hline $\begin{array}{l}\text { Nycticorax } \\
\text { nycticorax }\end{array}$ & $\begin{array}{c}\text { strictly } \\
\text { protected }\end{array}$ & 1 & 0 & 0 & 0 & wetland & 108.5 & 689 & 6.3502 & 1 & 0 \\
\hline Ardeola ralloides & $\begin{array}{c}\text { strictly } \\
\text { prtotected }\end{array}$ & 4 & 3 & 0 & 0 & wetland & 86 & 300 & 3.4884 & 1 & 0 \\
\hline Ardea cinerea & protected & 4 & 10 & 0 & 1 & wetland & 185 & 1546.5 & 8.3595 & 1 & 0 \\
\hline Ardea purpurea & $\begin{array}{c}\text { strictly } \\
\text { protected }\end{array}$ & 4 & 0 & 0 & 0 & wetland & 135 & 873.75 & 6.4722 & 1 & 0 \\
\hline $\begin{array}{l}\text { Ardea cinereal } \\
\text { purpurea }\end{array}$ & - & 1 & 0 & 0 & 0 & wetland & - & - & - & 1 & 0 \\
\hline Ardea alba & $\begin{array}{c}\text { strictly } \\
\text { protected }\end{array}$ & 5 & 6 & 0 & 0 & wetland & 155 & 1200 & 7.7419 & 1 & 0 \\
\hline Egretta garzetta & $\begin{array}{c}\text { strictly } \\
\text { protected }\end{array}$ & 5 & 1 & 0 & 0 & wetland & 95 & 495 & 5.2105 & 1 & 0 \\
\hline \multicolumn{12}{|l|}{ Suliformes } \\
\hline $\begin{array}{l}\text { Microcarbo } \\
\text { pygmaeus }\end{array}$ & $\begin{array}{c}\text { strictly } \\
\text { protected }\end{array}$ & 0 & 1 & 0 & 0 & wetland & 85 & 717.5 & 8.4412 & 1 & 0 \\
\hline
\end{tabular}


T. Nagy, J. Puskás \& R. Enyedi

\begin{tabular}{|c|c|c|c|c|c|c|c|c|c|c|c|}
\hline \multirow[b]{2}{*}{ Order/Species } & \multirow{2}{*}{$\begin{array}{c}\text { Conserva- } \\
\text { tion } \\
\text { status in } \\
\text { Hungary }\end{array}$} & \multicolumn{4}{|c|}{$\begin{array}{l}\text { Type of power } \\
\text { line }\end{array}$} & \multirow[b]{2}{*}{ Habitat } & \multirow[b]{2}{*}{ WS } & \multirow[b]{2}{*}{ W } & \multirow[b]{2}{*}{ WLP } & \multirow[b]{2}{*}{$\mathbf{T}$} & \multirow[b]{2}{*}{$\mathrm{u}$} \\
\hline & & 主 & $\frac{\text { dे }}{\frac{\partial}{0}}$ & 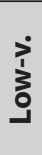 & 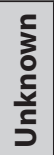 & & & & & & \\
\hline $\begin{array}{l}\text { Phalacrocorax } \\
\text { carbo }\end{array}$ & protected & 2 & 0 & 0 & 0 & wetland & 145 & 2310 & 15.9310 & 1 & 0 \\
\hline \multicolumn{12}{|l|}{ Charadriiformes } \\
\hline $\begin{array}{l}\text { Recurvirostra } \\
\text { avosetta }\end{array}$ & $\begin{array}{l}\text { strictly } \\
\text { protected }\end{array}$ & 0 & 1 & 0 & 0 & wetland & 73.5 & 296 & 4.0272 & 0 & 0 \\
\hline $\begin{array}{l}\text { Charadrius } \\
\text { alexandrinus }\end{array}$ & $\begin{array}{c}\text { strictly } \\
\text { protected }\end{array}$ & 0 & 0 & 0 & 1 & wetland & 43.5 & 44 & 1.0115 & 0 & 0 \\
\hline Vanellus vanellus & protected & 17 & 1 & 0 & 0 & $\begin{array}{l}\text { wetland- } \\
\text { farmland }\end{array}$ & 84.5 & 229 & 2.7101 & 1 & 0 \\
\hline $\begin{array}{l}\text { Numenius } \\
\text { phaeopus }\end{array}$ & protected & 1 & 0 & 0 & 0 & $\begin{array}{l}\text { wetland- } \\
\text { farmland }\end{array}$ & 82.5 & 433.25 & 5.2515 & 1 & 0 \\
\hline $\begin{array}{l}\text { Numenius } \\
\text { arquata }\end{array}$ & $\begin{array}{l}\text { strictly } \\
\text { protected }\end{array}$ & 2 & 0 & 0 & 0 & $\begin{array}{l}\text { wetland- } \\
\text { farmland }\end{array}$ & 90 & 813.75 & 9.0417 & 1 & 0 \\
\hline Limosa limosa & $\begin{array}{c}\text { strictly } \\
\text { protected }\end{array}$ & 2 & 1 & 0 & 0 & wetland & 76 & 336 & 4.4211 & 0 & 0 \\
\hline Calidris pugnax & protected & 1 & 0 & 0 & 0 & wetland & 53 & 156 & 2.9434 & 0 & 0 \\
\hline Calidris alba & protected & 0 & 1 & 0 & 0 & wetland & 37 & 75 & 2.0270 & 0 & 0 \\
\hline $\begin{array}{l}\text { Gallinago } \\
\text { gallinago }\end{array}$ & $\begin{array}{c}\text { strictly } \\
\text { protected }\end{array}$ & 3 & 0 & 0 & 0 & wetland & 45.5 & 126.5 & 2.7802 & 0 & 0 \\
\hline Tringa erythropus & protected & 0 & 1 & 0 & 0 & wetland & 64 & 163.5 & 2.5547 & 0 & 0 \\
\hline Tringa totanus & $\begin{array}{l}\text { strictly } \\
\text { protected }\end{array}$ & 1 & 0 & 0 & 0 & wetland & 62.5 & 120 & 1.9200 & 0 & 0 \\
\hline Tringa glareola & protected & 4 & 0 & 0 & 0 & wetland & 55.5 & 66 & 1.1892 & 0 & 0 \\
\hline Larus ridibundus & protected & 104 & 10 & 0 & 0 & $\begin{array}{l}\text { wetland- } \\
\text { farmland }\end{array}$ & 100.5 & 260 & 2.5871 & 1 & 0 \\
\hline Larus michahellis & protected & 0 & 1 & 0 & 0 & $\begin{array}{l}\text { wetland- } \\
\text { farmland }\end{array}$ & 130 & 1010 & 7.7692 & 1 & 0 \\
\hline Larus cachinnans & protected & 1 & 1 & 0 & 0 & $\begin{array}{l}\text { wetland- } \\
\text { farmland }\end{array}$ & 141 & 1090 & 7.7305 & 1 & 0 \\
\hline $\begin{array}{l}\text { Larus michahellis/ } \\
\text { cachinnans }\end{array}$ & protected & 5 & 0 & 0 & 0 & $\begin{array}{l}\text { wetland- } \\
\text { farmland }\end{array}$ & - & - & - & 1 & 0 \\
\hline $\begin{array}{l}\text { Hydroprogne } \\
\text { caspia }\end{array}$ & protected & 1 & 0 & 0 & 0 & wetland & 134.5 & 678 & 5.0409 & 0 & 0 \\
\hline $\begin{array}{l}\text { Chlidonias } \\
\text { hybrida }\end{array}$ & $\begin{array}{l}\text { strictly } \\
\text { protected }\end{array}$ & 0 & 1 & 0 & 0 & wetland & 67 & 80.5 & 1.2015 & 1 & 0 \\
\hline Chlidonias niger & $\begin{array}{c}\text { strictly } \\
\text { protected }\end{array}$ & 1 & 0 & 0 & 0 & wetland & 61 & 73 & 1.1967 & 1 & 0 \\
\hline \multicolumn{12}{|l|}{ Strigiformes } \\
\hline Tyto alba & $\begin{array}{c}\text { strictly } \\
\text { protected }\end{array}$ & 1 & 0 & 0 & 0 & farmland & 89 & 321 & 3.6067 & 0 & 1 \\
\hline
\end{tabular}




\begin{tabular}{|c|c|c|c|c|c|c|c|c|c|c|c|}
\hline \multirow[b]{2}{*}{ Order/Species } & \multirow{2}{*}{$\begin{array}{c}\text { Conserva- } \\
\text { tion } \\
\text { status in } \\
\text { Hungary }\end{array}$} & \multicolumn{4}{|c|}{$\begin{array}{l}\text { Type of power } \\
\text { line }\end{array}$} & \multirow[b]{2}{*}{ Habitat } & \multirow[b]{2}{*}{ WS } & \multirow[b]{2}{*}{$\mathbf{w}$} & \multirow[b]{2}{*}{ WLP } & \multirow[b]{2}{*}{$\mathbf{T}$} & \multirow[b]{2}{*}{$\mathbf{U}$} \\
\hline & & 主 & $\frac{\dot{d}}{\frac{d}{0}}$ & إذج & 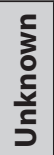 & & & & & & \\
\hline \multicolumn{12}{|l|}{ Accipitriformes } \\
\hline $\begin{array}{l}\text { Circus } \\
\text { aeruginosus }\end{array}$ & protected & 1 & 0 & 0 & 0 & $\begin{array}{l}\text { wetland- } \\
\text { farmland }\end{array}$ & 130 & 658.75 & 5.0673 & 0 & 0 \\
\hline \multicolumn{12}{|l|}{ Passeriformes } \\
\hline Corvus frugilegus & protected & 3 & 1 & 0 & 0 & farmland & 90 & 448 & 4.9778 & 1 & 1 \\
\hline Alauda arvensis & protected & 1 & 0 & 0 & 0 & farmland & 33 & 37.75 & 1.1439 & 0 & 0 \\
\hline Galerida cristata & protected & 1 & 0 & 0 & 0 & farmland & 33.5 & 42.5 & 1.2687 & 0 & 0 \\
\hline $\begin{array}{l}\text { Acrocephalus } \\
\text { schoenobaenus }\end{array}$ & protected & 4 & 0 & 0 & 0 & wetland & 19 & 13 & 0.6842 & 0 & 1 \\
\hline $\begin{array}{l}\text { Acrocephalus } \\
\text { scirpaceus }\end{array}$ & protected & 1 & 0 & 0 & 0 & wetland & 19 & 13.85 & 0.7289 & 0 & 1 \\
\hline Hirundo rustica & protected & 1 & 0 & 0 & 0 & farmland & 33 & 20 & 0.6061 & 1 & 1 \\
\hline Riparia riparia & protected & 1 & 0 & 0 & 0 & $\begin{array}{l}\text { wetland- } \\
\text { farmland }\end{array}$ & 27.5 & 15.25 & 0.5545 & 1 & 1 \\
\hline Sturnus vulgaris & protected & 3 & 6 & 0 & 0 & $\begin{array}{l}\text { farmland- } \\
\text { woodland }\end{array}$ & 39.5 & 77.5 & 1.9620 & 1 & 1 \\
\hline Muscicapa striata & protected & 1 & 0 & 0 & 0 & woodland & 24.5 & 16.55 & 0.6755 & 0 & 1 \\
\hline $\begin{array}{l}\text { Erithacus } \\
\text { rubecula }\end{array}$ & protected & 1 & 0 & 0 & 0 & woodland & 21 & 19.5 & 0.9286 & 0 & 0 \\
\hline Luscinia luscinia & $\begin{array}{l}\text { strictly } \\
\text { protected }\end{array}$ & 0 & 0 & 1 & 0 & woodland & 25 & 25.5 & 1.0200 & 0 & 0 \\
\hline
\end{tabular}

